\title{
Fine particle pH and gas-particle phase partitioning of inorganic species in Pasadena, California, during the 2010 CalNex campaign
}

\section{Hongyu Guo et al.}

Correspondence to: Rodney J. Weber (rweber@eas.gatech.edu) and Athanasios Nenes (athanasios.nenes@gatech.edu)

The copyright of individual parts of the supplement might differ from the CC BY 3.0 License. 


\section{Comparisons of inorganic species measurements between AMS (PM $\left.\mathbf{M}_{1}\right)$ and PILS-IC (PM 2.5$)$}

Consistency $\left(\mathrm{R}^{2} \geq 0.8\right)$ between AMS and PILS-IC was observed. AMS measured nominally $\mathrm{PM}_{1}$, whereas PILS-IC measured $\mathrm{PM}_{2.5}$. These results are similar with other inter-comparisons reported elsewhere (Hayes et al., 2013). A larger difference in slope for nitrate than sulfate is thought to be due to higher nitrate concentrations in the 1 to $2.5 \mu \mathrm{m}$ size range. $\mathrm{PM}_{1} / \mathrm{PM}_{2.5}$ mass ratios, reported in the main text, differ from slopes shown below due to differences in contributions of lower concentrations to these parameters (ratio vs. slope).
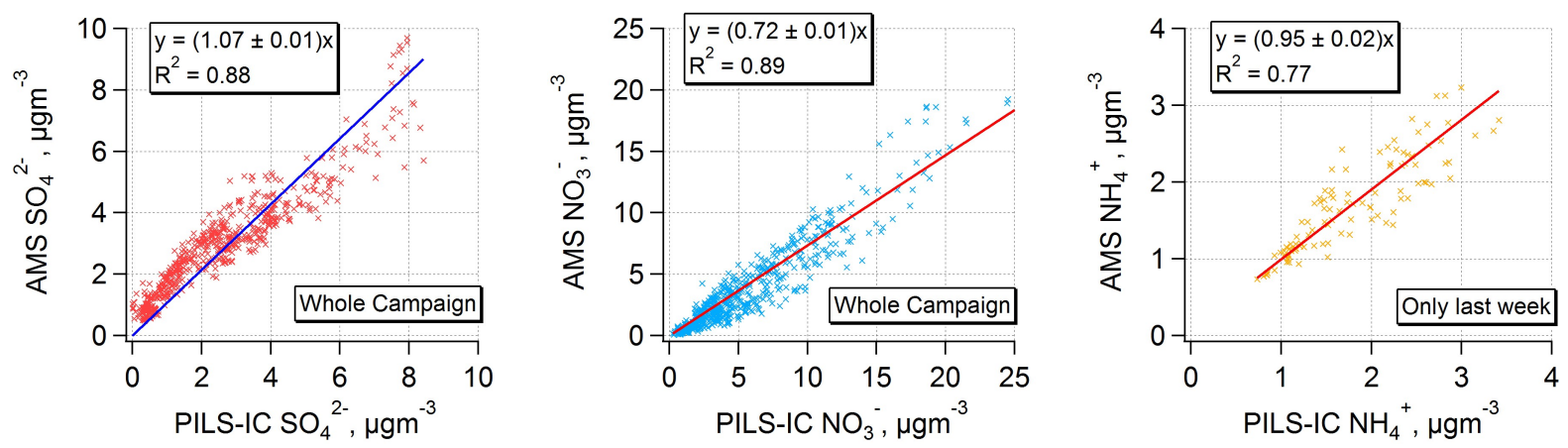

Fig. S1. Comparisons of $\mathrm{PM}_{1}$ AMS sulfate, nitrate, ammonium to $\mathrm{PM}_{2.5}$ PILS-IC (complete CalNex study except ammonium only for last week). Orthogonal distance regression (ODR) fits with fixed zero intercepts were applied. Fit slope uncertainty is one standard deviation. 


\section{The dependencies of nitrate, ammonium, and chloride on $\mathrm{pH}, W_{i}$, and $\mathrm{T}$ ( $\mathrm{S}$ curve equation derivations)}

\section{1 $\mathrm{HNO}_{3}-\mathrm{NO}_{3}{ }^{-}$partitioning}

The S curve of $\varepsilon\left(\mathrm{NO}_{3}{ }^{-}\right)$has been discussed explicitly and compared to observations from WINTER aircraft campaign in Guo et al. (2016). Here we show the detailed derivation of equation (3) in that paper. Equilibrium between gaseous $\mathrm{HNO}_{3}$ and particle-phase $\mathrm{NO}_{3}{ }^{-}$involves two processes, first dissolution of $\mathrm{HNO}_{3}$ into aqueous phase (assuming particles are liquids) and second dissociation of dissolved $\mathrm{HNO}_{3}$ into $\mathrm{H}^{+}$and $\mathrm{NO}_{3}{ }^{-}$. The two processes are reversible and often reach thermodynamic equilibriums at ambient conditions $(\mathrm{RH}, \mathrm{T})$ for fine particles.

$$
\begin{aligned}
& 1^{\text {st }} \mathrm{HNO}_{3(\mathrm{~g})} \leftrightarrow \mathrm{HNO}_{3}, \mathrm{H}_{\mathrm{HNO}_{3}} \\
& 2^{\text {nd }} \mathrm{HNO}_{3} \leftrightarrow \mathrm{NO}_{3}{ }^{-}+\mathrm{H}^{+}, \quad \mathrm{K}_{n 1}
\end{aligned}
$$

for which reaction equilibriums are expressed as follows,

$$
\begin{gathered}
\mathrm{H}_{\mathrm{HNO}_{3}}=\gamma_{\mathrm{HNO}_{3}}\left[\mathrm{HNO}_{3}\right] / p_{\mathrm{HNO}_{3}} \\
K_{n 1}=\frac{\gamma_{\mathrm{NO}_{3}}{ }^{-}\left[\mathrm{NO}_{3}{ }^{-}\right] \gamma_{\mathrm{H}^{+}}\left[\mathrm{H}^{+}\right]}{\gamma_{\mathrm{HNO}_{3}}\left[\mathrm{HNO}_{3}\right]}
\end{gathered}
$$

where $\mathrm{H}_{\mathrm{HNO}_{3}}$ is $\mathrm{HNO}_{3}$ Henry's law constant, $K_{n 1}$ is $\mathrm{HNO}_{3}$ acid dissociation constant, $\gamma$ represents activity coefficient, $p_{\mathrm{HNO}_{3}}$ is partial pressure of $\mathrm{HNO}_{3}$ in atmosphere, and $[\mathrm{x}]$ represents aqueous concentrations (mole $\mathrm{L}^{-1}$ ). From equations (1) and (2) we get the total dissolved $\mathrm{HNO}_{3}$ or total particlephase nitrate $\left(\mathrm{NO}_{3}{ }^{\mathrm{T}}\right)$ as

$$
\left[\mathrm{NO}_{3}{ }^{\mathrm{T}}\right]=\left[\mathrm{HNO}_{3}\right]+\left[\mathrm{NO}_{3}{ }^{-}\right]=\mathrm{H}_{\mathrm{HNO}_{3}} p_{\mathrm{HNO}_{3}}\left(\frac{1}{\gamma_{\mathrm{HNO}_{3}}}+\frac{K_{n 1}}{\gamma_{\mathrm{NO}_{3}}-\gamma_{\mathrm{H}^{+}}\left[\mathrm{H}^{+}\right]}\right)
$$

Ideal gas law gives

$$
c\left(\mathrm{HNO}_{3}\right)=\frac{p_{\mathrm{HNO}_{3}}}{R T}
$$

where $c(\mathrm{x})$ represents concentration per volume of air $\left(\mathrm{mole}^{-3}\right)$. Therefore, the particle-phase fraction of nitrate is

$$
\varepsilon\left(N O_{3}{ }^{\mathrm{T}}\right)=\frac{c\left(N O_{3}^{T}\right)}{c\left(H N O_{3}\right)+c\left(N O_{3}^{T}\right)}=\frac{\left[N O_{3}^{T}\right] W_{i}}{c\left(H N O_{3}\right)+\left[N O_{3}^{T}\right] W_{i}}
$$

where $W_{i}$ is the particle liquid water content associated with inorganic species $\left(\mu \mathrm{g} \mathrm{m}^{-3}\right.$; mass per volume of air) (here the organics associated liquid water is not considered, but it can be included, or measured particle water can be used). Taking equations (3) and (4) into (5), we get $\varepsilon\left(\mathrm{NO}_{3}{ }^{\mathrm{T}}\right)$ as 


$$
\varepsilon\left(\mathrm{NO}_{3}{ }^{\mathrm{T}}\right)=\frac{\left(\frac{\gamma_{\mathrm{NO}_{3}}-\gamma_{\mathrm{H}^{+}}}{\gamma_{\mathrm{HNO}_{3}}}\left[\mathrm{H}^{+}\right]+K_{n 1}\right) H_{\mathrm{HNO}_{3}} W_{i} R T}{\gamma_{\mathrm{NO}_{3}}{ }^{-} \gamma_{\mathrm{H}^{+}}\left[\mathrm{H}^{+}\right]+\left(\frac{\gamma_{\mathrm{NO}_{3}}-\gamma_{\mathrm{H}^{+}}}{\gamma_{\mathrm{HNO}_{3}}}\left[\mathrm{H}^{+}\right]+K_{n 1}\right) \mathrm{H}_{\mathrm{HNO}_{3}} W_{i} R T}
$$

At $298 \mathrm{~K}, K_{n 1}=12$ mole L ${ }^{-1}$ (Fountoukis and Nenes, 2007) often $>>\frac{\gamma_{\mathrm{NO}_{3}} \gamma_{\mathrm{H}^{+}}}{\gamma_{\mathrm{HNO}_{3}}}\left[\mathrm{H}^{+}\right]$, so we assume $\left(\frac{\gamma_{\mathrm{NO}_{3}}-\gamma_{\mathrm{H}^{+}}}{\gamma_{\mathrm{HNO}_{3}}}\left[\mathrm{H}^{+}\right]+K_{n 1}\right) \approx K_{n 1}$. Thus, a simplified equation is

$$
\varepsilon\left(\mathrm{NO}_{3}{ }^{\mathrm{T}}\right) \cong \frac{K_{n 1} \mathrm{H}_{\mathrm{HNO}_{3}} W_{i} R T}{\gamma_{\mathrm{NO}_{3}}{ }^{-} \gamma_{\mathrm{H}^{+}}\left[\mathrm{H}^{+}\right]+K_{n 1} \mathrm{H}_{\mathrm{HNO}_{3}} W_{i} R T}
$$

$H_{\mathrm{HNO}_{3}} K_{n 1}$ is denoted as $\mathrm{H}_{\mathrm{HNO}_{3}}^{*}\left(\right.$ mole $\left.^{2} \mathrm{~kg}^{-2} \mathrm{~atm}^{-1}\right)$ hereafter, which is equilibrium constant of the combined dissolution and deprotonation processes as,

$$
\mathrm{HNO}_{3(\mathrm{~g})} \leftrightarrow \mathrm{NO}_{3}{ }^{-}+\mathrm{H}^{+}, \mathrm{H}_{\mathrm{HNO}_{3}}^{*}
$$

$\mathrm{H}_{\mathrm{HNO}_{3}}^{*}$ can be easily calculated by equation (40) in Clegg and Brimblecombe (1990) for T dependence and converted from unit atm ${ }^{-1}$ (mole fraction based) to mole $\mathrm{kg}^{-2} \mathrm{~atm}^{-1}$ (molality based) by equation (5) also in that paper. To be consistent with SI units, we have the following equation ready for users' input:

$$
\begin{aligned}
& \varepsilon\left(\mathrm{NO}_{3}{ }^{\mathrm{T}}\right) \cong \frac{H_{\mathrm{HNO}_{3}}^{*} W_{i} R T \times 0.987 \times 10^{-14}}{\gamma_{\mathrm{NO}_{3}}{ }^{-} \gamma_{H^{+}}\left[H^{+}\right]+H_{H N O_{3}}^{*} W_{i} R T \times 0.987 \times 10^{-14}} \\
& =\frac{H_{\mathrm{HNO}_{3}}^{*} W_{i} R T \times 0.987 \times 10^{-14}}{\gamma_{\mathrm{NO}_{3}}-\gamma_{\mathrm{H}^{+}} 10^{-p H}+H_{\mathrm{HNO} O_{3}}^{*} W_{i} R T \times 0.987 \times 10^{-14}}
\end{aligned}
$$

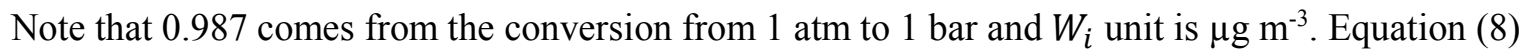
describes the dependence of $\mathrm{HNO}_{3}-\mathrm{NO}_{3}{ }^{-}$partitioning on $\mathrm{pH}, \mathrm{T}$, and $W_{i}$ (determined by $\mathrm{RH}$ and aerosol composition). Based on ideal and non-ideal aqueous particles, several $\varepsilon\left(\mathrm{NO}_{3}{ }^{-}\right) \mathrm{S}$ curves at atmosphere relevant conditions are plotted together with $\varepsilon\left(\mathrm{Cl}^{-}\right)$and $\varepsilon\left(\mathrm{NH}_{4}{ }^{+}\right)$in Fig S3 and S4, respectively. $\varepsilon\left(\mathrm{NO}_{3}{ }^{\mathrm{T}}\right)$ is equivalent to $\varepsilon\left(\mathrm{NO}_{3}{ }^{-}\right)$in the main text, since $\mathrm{NO}_{3}{ }^{-}$is practically $100 \%$ of $\mathrm{NO}_{3}{ }^{\mathrm{T}}$ based on $K_{n 1} \gg \frac{\gamma_{\mathrm{NO}_{3}}-\gamma_{\mathrm{H}^{+}}}{\gamma_{\mathrm{HNO}_{3}}}\left[\mathrm{H}^{+}\right]$(also under atmospheric condition). The fraction of $\mathrm{NO}_{3}{ }^{-}$over $\mathrm{NO}_{3}{ }^{\mathrm{T}}$ can be given as

$$
\frac{\left[\mathrm{NO}_{3}{ }^{-}\right]}{\left[\mathrm{NO}_{3}^{\mathrm{T}}\right]}=\frac{K_{n 1}}{K_{n 1}+\frac{\gamma_{\mathrm{NO}_{3}}{ }^{-} \gamma_{H^{+}}}{\gamma_{\mathrm{HNO}_{3}}}\left[\mathrm{H}^{+}\right]}
$$

\section{2 $\mathrm{HCl}-\mathrm{Cl}^{-}$partitioning}

Following the same derivation procedure as $\mathrm{HNO}_{3}-\mathrm{NO}_{3}{ }^{-}$partitioning, we have $\varepsilon\left(\mathrm{Cl}^{-}\right)$as 


$$
\begin{array}{r}
\varepsilon\left(C l^{-}\right) \cong \frac{H_{H C l}^{*} W_{i} R T \times 0.987 \times 10^{-14}}{\gamma_{C l^{-}} \gamma_{H^{+}}\left[H^{+}\right]+H_{H C l}^{*} W_{i} R T \times 0.987 \times 10^{-14}} \\
=\frac{H_{H C l}^{*} W_{i} R T \times 0.987 \times 10^{-14}}{\gamma_{C l^{-}} \gamma_{H^{+}} 10^{-p H}+H_{H C l}^{*} W_{i} R T \times 0.987 \times 10^{-14}}
\end{array}
$$

where $H_{H C l}^{*}\left(m_{0} \mathrm{~kg}^{-2} \mathrm{~atm}^{-1}\right)$ is the equilibrium constant and is equal to the "conventional" Henry's law constant multiplied by the acid dissociation constant of hydrochloric acid. $H_{H C l}^{*}$ can be calculated by equation (22) in Carslaw et al. (1995) to account for T's variation.

$$
\mathrm{HCl}_{(g)} \leftrightarrow \mathrm{Cl}^{-}+\mathrm{H}^{+}, \mathrm{H}_{\mathrm{HCl}}^{*}
$$

A comparison of $\varepsilon\left(\mathrm{Cl}^{-}\right) \mathrm{S}$ curve with a subset of CalNex data is shown in Fig. S2. The selected CalNex data are all in a small range of $\mathrm{T} 15.5$ to $19.5^{\circ} \mathrm{C}$ (around campaign average $\mathrm{T}$ ) and $W_{i} 10$ to $20 \mu \mathrm{g} \mathrm{m}^{-3}$, while the $\mathrm{S}$ curve is calculated based on the average condition of these data as $\mathrm{T}=17.5^{\circ} \mathrm{C}, W_{i}=15 \mu \mathrm{g} \mathrm{m}$ ${ }^{3}, \gamma_{\mathrm{H}^{+}-\mathrm{Cl}^{-}}=0.81$ (The binary activity coefficient, $\gamma_{\mathrm{H}^{+}-\mathrm{Cl}^{-}}=\sqrt{\gamma_{\mathrm{H}^{+}} \gamma_{C l^{-}}}$). The distribution of the $\varepsilon\left(\mathrm{Cl}^{-}\right)$ points close to $\mathrm{S}$ curve validates the $\mathrm{PM}_{2.5} \mathrm{pH}$ prediction and demonstrates the usage of $\mathrm{S}$ curve.

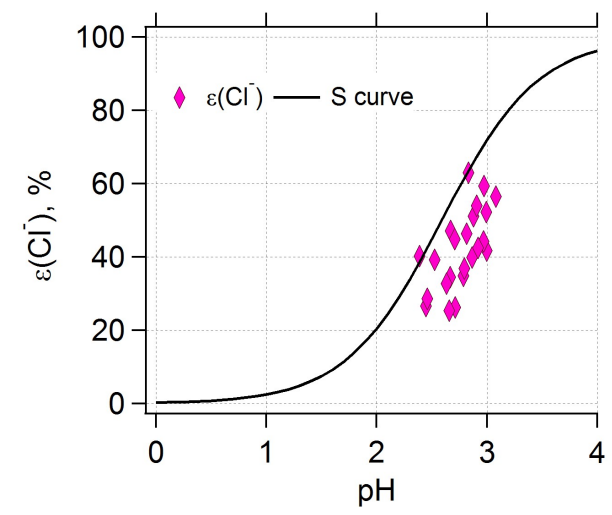

Fig. S2. The comparison of S curve and measured $\varepsilon\left(\mathrm{Cl}^{-}\right)$with predicted particle $\mathrm{pH}$ by ISORROPIA-II. $\mathrm{Cl}^{-}$is from $\mathrm{PM}_{2.5}$ PILS-IC measurements.

\section{3 $\mathrm{NH}_{3}-\mathrm{NH}_{4}{ }^{+}$partitioning}

The derivation of $\mathrm{NH}_{3}-\mathrm{NH}_{4}{ }^{+}$partitioning is a bit different from the above two acidic gases. Equilibrium between gaseous $\mathrm{NH}_{3}$ and $\mathrm{NH}_{4}^{+}$can be described simply as

$$
\mathrm{NH}_{3(\mathrm{~g})}+\mathrm{H}^{+} \leftrightarrow \mathrm{NH}_{4}^{+}, \mathrm{H}_{\mathrm{NH}_{3}}^{*}
$$

( $H_{\mathrm{NH}_{3}}^{*}$ is equivalent to the "conventional" Henry's law constant of $\mathrm{NH}_{3}$ divided by the acid dissociation constant of $\mathrm{NH}_{4}^{+}$) or described by the follow two reversible reactions assuming water activity as unity. 
Fine particle $\mathrm{pH}$ and gas-particle phase partitioning of inorganics during the 2010 CalNex campaign

$$
\begin{array}{ll}
1^{\text {st }} \mathrm{NH}_{3(\mathrm{~g})} \leftrightarrow \mathrm{NH}_{3}, \quad H_{\mathrm{NH}_{3}} \\
2^{\text {nd }} \mathrm{NH}_{3}+\mathrm{H}^{+} \leftrightarrow \mathrm{NH}_{4}{ }^{+}, 1 / K_{a}
\end{array}
$$

for which reaction equilibriums are described as

$$
\begin{gathered}
H_{\mathrm{NH}_{3}}=\gamma_{\mathrm{NH}_{3}}\left[\mathrm{NH}_{3}\right] / p_{\mathrm{NH}_{3}} \\
1 / K_{a}=\frac{\gamma_{\mathrm{NH}_{4}}\left[\mathrm{NH}_{4}{ }^{+}\right]}{\gamma_{\mathrm{NH}_{3}}\left[\mathrm{NH}_{3}\right] \gamma_{\mathrm{H}^{+}}\left[\mathrm{H}^{+}\right]}
\end{gathered}
$$

where $H_{N_{3}}$ is $\mathrm{NH}_{3}$ Henry's law constant, $K_{a}$ is $\mathrm{NH}_{4}{ }^{+}$acid dissociation constant, $\gamma$ represents activity coefficient, $p_{\mathrm{NH}_{3}}$ is partial pressure of $\mathrm{NH}_{3}$ in atmosphere, and [x] represents aqueous concentrations (mole $\mathrm{L}^{-1}$ ). Please note that the $2^{\text {nd }}$ reaction is usually written in another form (Fountoukis and Nenes, 2007) as

$$
2^{\text {nd }} \mathrm{NH}_{3}+\mathrm{H}_{2} \mathrm{O} \leftrightarrow \mathrm{NH}_{4}^{+}+\mathrm{OH}^{-}, \quad \mathrm{K}_{w} / \mathrm{K}_{a}
$$

where $K_{w}$ is water dissociation constant. Equations (10) and (11) give the total dissolved $\mathrm{NH}_{3}$ or total particle-phase ammonium $\left(\mathrm{NH}_{4}{ }^{\mathrm{T}}\right)$ as

$$
\left[N H_{4}^{T}\right]=\left[N H_{3}\right]+\left[N H_{4}^{+}\right]=H_{N H_{3}} p_{N H_{3}}\left(\frac{1}{\gamma_{N H_{3}}}+\frac{\gamma_{H^{+}}\left[H^{+}\right]}{\gamma_{N H_{4}}+K_{a}}\right)
$$

Combining with ideal gas law, that is

$$
c\left(N_{3}\right)=\frac{p_{N H_{3}}}{R T}
$$

where $c(\mathrm{x})$ represents concentration per volume of air $\left(\mathrm{mole}^{-3}\right)$. We have the particle-phase fraction of ammonium as

$$
\varepsilon\left(N H_{4}{ }^{\mathrm{T}}\right)=\frac{c\left(N H_{4}^{T}\right)}{c\left(N H_{3}\right)+c\left(N H_{4}^{T}\right)}=\frac{\left[N H_{4}^{T}\right] W_{i}}{c\left(N H_{3}\right)+\left[N H_{4}^{T}\right] W_{i}}
$$

With equations (12) and (13), the above equation is transformed into

$$
\varepsilon\left(N H_{4}{ }^{\mathrm{T}}\right)=\frac{\left(\frac{\gamma_{H^{+}}\left[H^{+}\right]}{\gamma_{N H_{4}}{ }^{+}}+\frac{K_{a}}{\gamma_{N H_{3}}}\right) \frac{H_{N H_{3}}}{K_{a}} W_{i} R T}{1+\left(\frac{\gamma_{H^{+}}\left[H^{+}\right]}{\gamma_{N H_{4}}{ }^{+}}+\frac{K_{a}}{\gamma_{N H_{3}}}\right) \frac{H_{N H_{3}}}{K_{a}} W_{i} R T}
$$

At $298 \mathrm{~K}, K_{a}=5.69 \times 10^{-10}$ mole L-1 (Clegg et al., 1998) results in $\frac{K_{a}}{\gamma_{N_{3}}} \ll \frac{\gamma_{H^{+}}\left[H^{+}\right]}{\gamma_{N H_{4}}{ }^{+}}$as long as the solution is not too basic. Neglecting $\frac{K_{a}}{\gamma_{N_{3}}}$ part and taking $\frac{H_{N H_{3}}}{K_{a}}=H_{N H_{3}}^{*}$, we have

$$
\varepsilon\left(N H_{4}{ }^{\mathrm{T}}\right) \cong \frac{\frac{\gamma_{H^{+}}\left[H^{+}\right]}{\gamma_{N H_{4}{ }^{+}}} H_{N H_{3}}^{*} W_{i} R T}{1+\frac{\gamma_{H^{+}}\left[H^{+}\right]}{\gamma_{N_{4}{ }^{+}}{ }^{+}} H_{N H_{3}}^{*} W_{i} R T}
$$


To be consistent with SI units, the equation (16) is then presented as:

$$
\begin{array}{r}
\varepsilon\left(N H_{4}^{\mathrm{T}}\right) \cong \frac{\frac{\gamma_{H^{+}}\left[H^{+}\right]}{\gamma_{N H_{4}}{ }^{+}} H_{N H_{3}}^{*} W_{i} R T \times 0.987 \times 10^{-14}}{1+\frac{\gamma_{H^{+}}\left[H^{+}\right]}{\gamma_{N H_{4}}{ }^{+}} H_{N H_{3}}^{*} W_{i} R T \times 0.987 \times 10^{-14}} \\
=\frac{\frac{\gamma_{H^{+}} 10^{-p H}}{\gamma_{N H_{4}}{ }^{-}} H_{N H_{3}}^{*} W_{i} R T \times 0.987 \times 10^{-14}}{1+\frac{\gamma_{H^{+}} 10^{-p H}}{\gamma_{N H_{4}}{ }^{+}} H_{N H_{3}}^{*} W_{i} R T \times 0.987 \times 10^{-14}}
\end{array}
$$

where the 0.987 comes from the conversion from $1 \mathrm{~atm}$ to $1 \mathrm{bar}$ and $W_{i}$ unit is $\mu \mathrm{g} \mathrm{m}^{-3} . H_{N H_{3}}^{*}\left(\mathrm{~atm}^{-1}\right)$ can be calculated from equation (12) in Clegg et al. (1998) following a typo correction to the equation. The corrected equation is:

$$
\ln \left(H_{N H_{3}}^{*}\right)=25.393-10373.6\left(1 / T_{r}-1 / T\right)+4.131\left(T_{r} / T-\left(1+\ln \left(T_{r} / T\right)\right)\right)
$$

where $T_{r}$ is the reference temperature of $298.15 \mathrm{~K}$. Note that, the mole fraction based $H_{N H_{3}}^{*}$ has the same numerical value as its molality based form. After correction, a larger $H_{\mathrm{NH}_{3}}^{*}$ is associated with a lower temperature, consistent with a general expectation that $\mathrm{NH}_{3}$ condenses onto particles if temperature decreases. $\varepsilon\left(\mathrm{NH}_{4}{ }^{\mathrm{T}}\right)$ is equivalent to $\varepsilon\left(\mathrm{NH}_{4}{ }^{+}\right)$presented in the main text, since $\mathrm{NH}_{4}{ }^{+}$is the dominant form of dissolved $\mathrm{NH}_{3}$ based on $\frac{K_{a}}{\gamma_{N H_{3}}} \ll \frac{\gamma_{H^{+}}\left[H^{+}\right]}{\gamma_{N_{4}}{ }^{+}}$and under atmospheric conditions.

Summary: with the equations of $\varepsilon\left(\mathrm{NO}_{3}^{-}\right), \varepsilon\left(\mathrm{Cl}^{-}\right)$, and $\varepsilon\left(\mathrm{NH}_{4}{ }^{+}\right)$, S-shaped curves of these three paired gas to particle partitioning can be easily calculated with $\mathrm{pH}, \mathrm{T}, W_{i}$, and activity coefficients. We simulate two set of results, Fig S3 assuming activity coefficients to be one (ideal solution) and Fig S4 with practical activity coefficients from CalNex. 
(a)

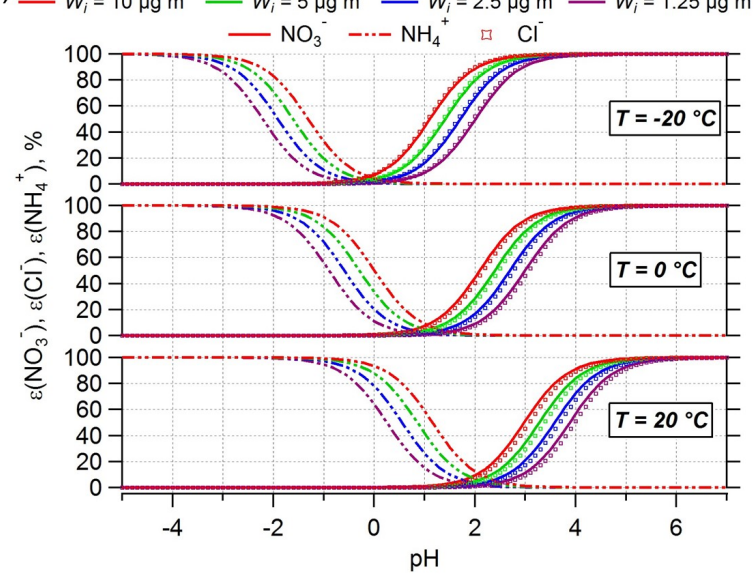

(b)

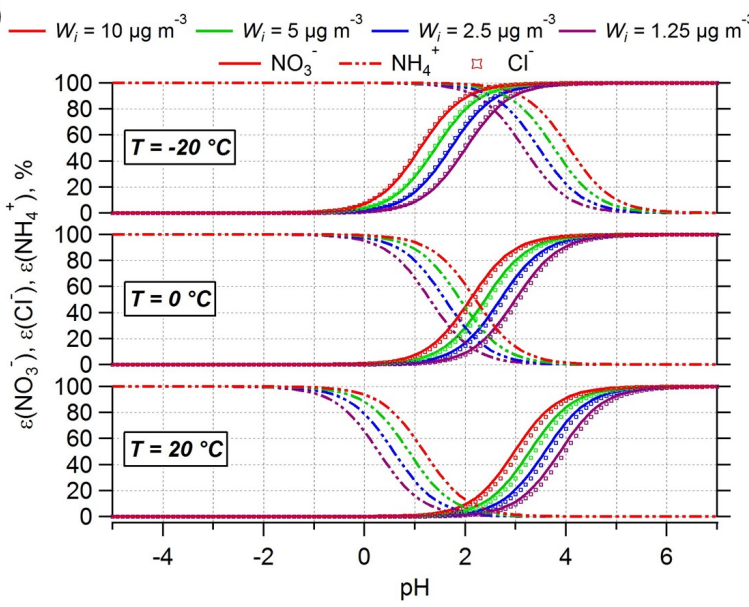

Fig. S3. Simulated $\varepsilon\left(\mathrm{NO}_{3}^{-}\right), \varepsilon\left(\mathrm{NH}_{4}^{+}\right), \varepsilon\left(\mathrm{Cl}^{-}\right)$at $-20{ }^{\circ} \mathrm{C}, 0{ }^{\circ} \mathrm{C}, 20{ }^{\circ} \mathrm{C}$ and various particle liquid water levels $\left(1.25,2.5,5,10 \mu \mathrm{g} \mathrm{m}^{-3}\right)$ assuming ideal solutions. Note that Fig. S3a shows $\varepsilon\left(\mathrm{NH}_{4}^{+}\right)$calculated using the equation (12) in Clegg et al. (1998), and Fig. S3b shows $\varepsilon\left(\mathrm{NH}_{4}^{+}\right)$using the corrected equation, given above as equation (19). The correct equation for $H_{N H_{3}}^{*}$ shifts $\varepsilon\left(\mathrm{NH}_{4}{ }^{+}\right)$to higher $\mathrm{pH}$ at lower $\mathrm{T}$, as expected.

(a)

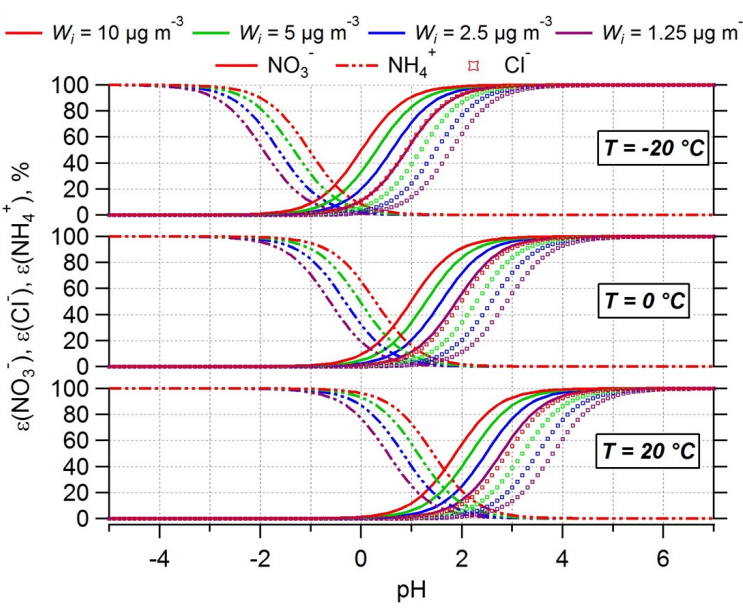

(b)

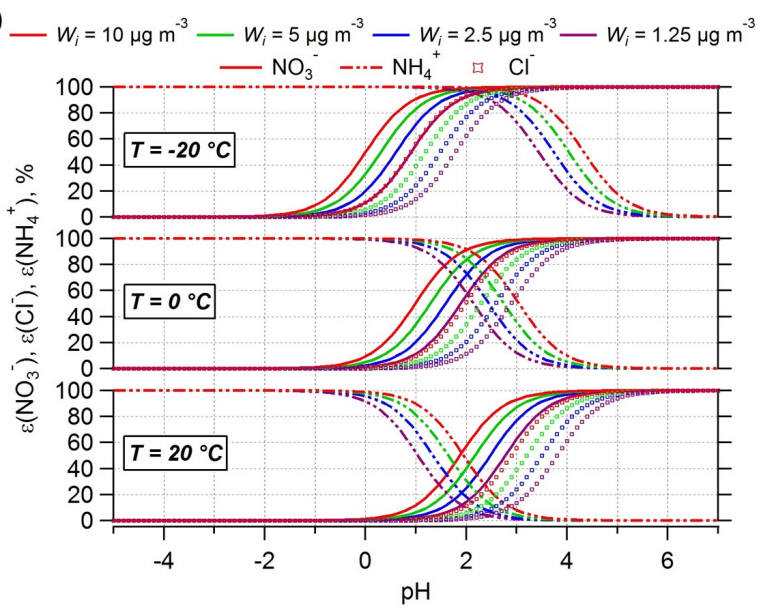

Fig. S4. Simulated $\varepsilon\left(\mathrm{NO}_{3}{ }^{-}\right), \varepsilon\left(\mathrm{NH}_{4}{ }^{+}\right), \varepsilon\left(\mathrm{Cl}^{-}\right)$at $-20{ }^{\circ} \mathrm{C}, 0{ }^{\circ} \mathrm{C}, 20{ }^{\circ} \mathrm{C}$ and various particle liquid water levels $\left(1.25,2.5,5,10 \mu \mathrm{g} \mathrm{m}^{-3}\right)$ with activity coefficients obtained from CalNex campaign. $\gamma_{\mathrm{H}^{+}-\mathrm{NO}_{3}^{-}}=0.28$, $\gamma_{H^{+}-C l^{-}}=0.81$, and $\gamma_{H^{+}} / \gamma_{N_{4}^{+}}=1.90$. Similar to Fig. S3, Fig. S4a shows $\varepsilon\left(\mathrm{NH}_{4}^{+}\right)$calculated using the equation (12) in Clegg et al. (1998), and Fig. S4b shows $\varepsilon\left(\mathrm{NH}_{4}^{+}\right)$using the corrected equation, given above as equation (19). 


\section{Investigation of the cause for bias in $\varepsilon\left(\mathrm{NO}_{3}{ }^{-}\right)$: sample line heating?}

As Fig. S5 shows, $\mathrm{NO}_{3}{ }^{-}$and $\varepsilon\left(\mathrm{NO}_{3}{ }^{-}\right)$are both over-predicted during the nighttime and under-predicted during the daytime. The deviations from measurements are anti-correlated with nitric acid. The deviation between predicted and measured $\mathrm{HNO}_{3}$ also has a diurnal pattern, reverse to that of $\mathrm{NO}_{3}{ }^{-}$.

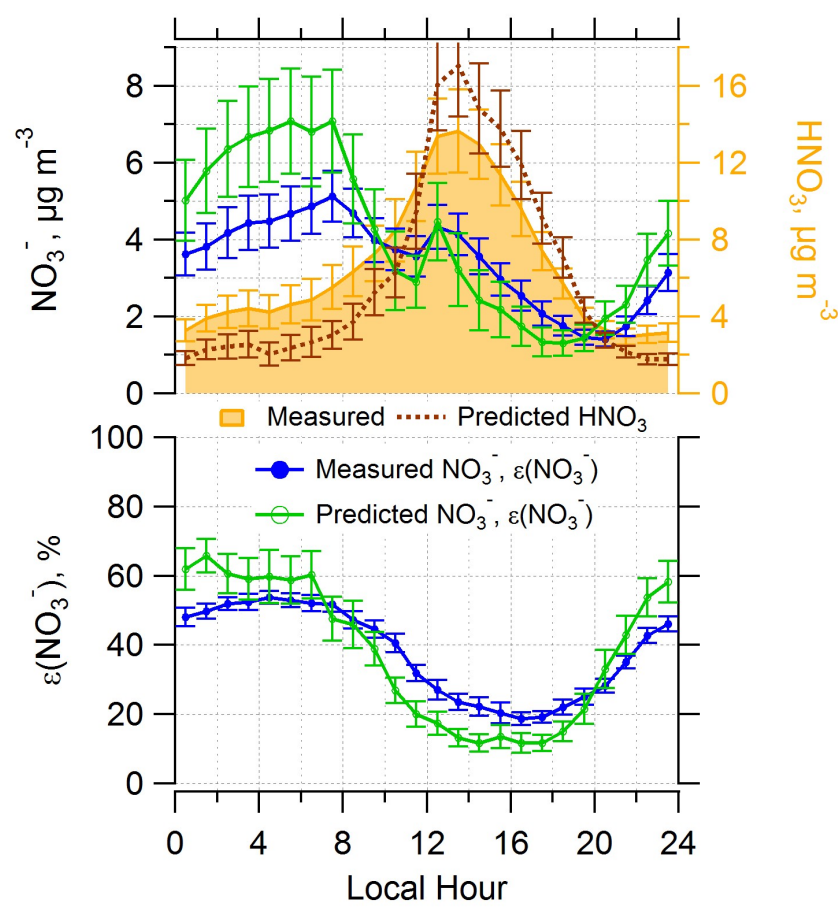

Fig. S5. Diurnal profiles of measured and predicted $\mathrm{HNO}_{3}, \mathrm{NO}_{3}{ }^{-}$, and $\varepsilon\left(\mathrm{NO}_{3}{ }^{-}\right)$. Data shown above are for the complete CalNex study and particle-phase data is AMS $\mathrm{PM}_{1}$. Mean hourly averages are shown and standard errors are plotted as error bars.

Table S1. Summary of temperature differences in sample lines and ambient and sample line residence time for the AMS and CIMS. AMS indoor T was $25^{\circ} \mathrm{C}$. CIMS inlet was heated to $75^{\circ} \mathrm{C}$.

\begin{tabular}{l|c|c|c}
\hline Instrument & $\begin{array}{c}\text { Inlet residence } \\
\text { time, sec }\end{array}$ & Time of the day & $\begin{array}{c}\text { Temperature } \\
\text { differences, }{ }^{\circ} \mathrm{C}\end{array}$ \\
\hline AMS & 2.1 & $\begin{array}{c}\text { Day } \\
\text { Night }\end{array}$ & $\sim 0$ \\
CIMS & 0.32 & Day & $\sim+10$ \\
\hline
\end{tabular}


For the AMS sample line located indoors, particle heating was most likely to occur at night (indoor T > ambient T), which may cause semi-volatile $\mathrm{NO}_{3}{ }^{-}$loss. There were no temperature differences during the day (Table S1). To examine the possible sample line heating/cooling effect, we first determined sample line RH (Equation 20) by conservation of water vapor under isobaric condition and following saturated water vapor pressure equation $e_{S}=6.11 \times 10^{\left(\frac{7.5 T}{237.5+T}\right)}\left(\mathrm{T}\right.$ unit as $\left.{ }^{\circ} \mathrm{C}\right)$ (Alduchov and Eskridge, 1996). The inferred sample line RH is plotted with measured ambient RH in Fig. S6b. Sample line RH was lower ( $\sim 50 \%)$ than ambient ( $\sim 90 \%)$ at midnight and close to ambient $(\sim 60 \%)$ in the afternoon since temperatures were similar.

$$
R H_{2}=R H_{1} 10^{\left[\left(\frac{7.5 T_{1}}{237.5+T_{1}}\right)-\left(\frac{7.5 T_{2}}{237.5+T_{2}}\right)\right]}
$$
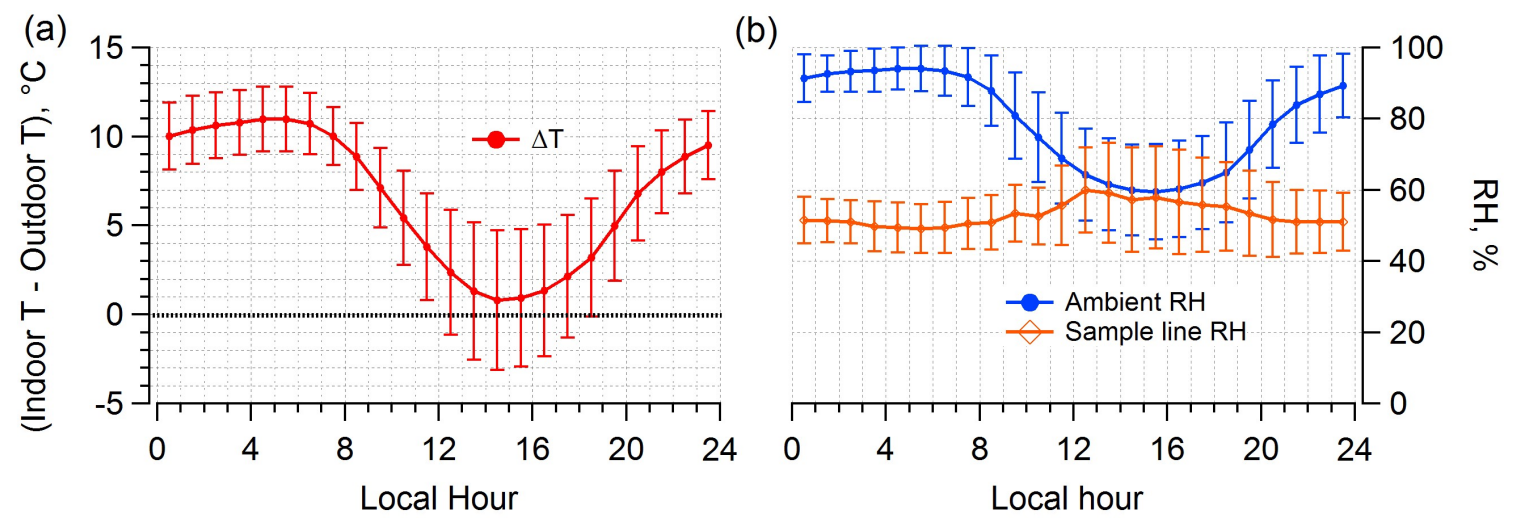

Fig. S6. Diurnal profiles of (a) temperature difference between AMS indoor and outdoor and (b) corresponding ambient and RH predicted in the sample line due to the T difference. Mean hourly averages and standard deviations are shown.

ISORROPIA-II was run with aerosol and gas-phase species at the AMS sample line T and RH and compared to predictions from ambient $\mathrm{T}$ and $\mathrm{RH}$ and measurements. Fig. S7 is discussed in the main text section 4.1 . 

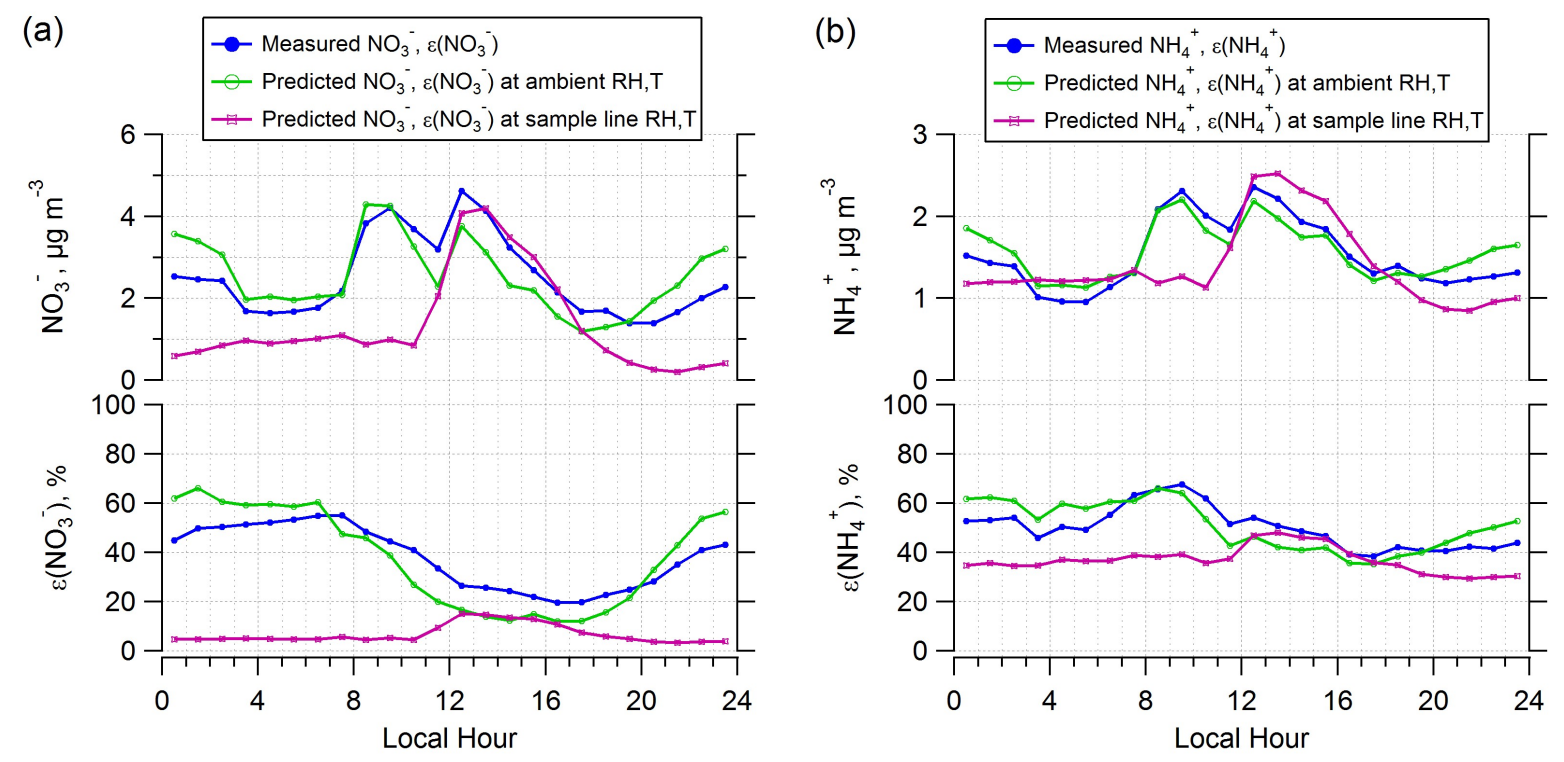

Fig. S7. Diurnal profiles of measured and predicted (a) $\mathrm{NO}_{3}{ }^{-}, \varepsilon\left(\mathrm{NO}_{3}{ }^{-}\right)$and (b) $\mathrm{NH}_{4}{ }^{+}, \varepsilon\left(\mathrm{NH}_{4}{ }^{+}\right)$. Predictions are based on ambient or sample line RH and T for AMS inlet. Data shown above are for the complete CalNex study in the 20-95\% RH range and particle-phase data is AMS $\mathrm{PM}_{1}$. Mean hourly averages are shown. ISORROPIA run with ambient data show that the predicted partitioning between the particle and gas phase is in better agreement with observations than runs using sample line $\mathrm{T}$ and $\mathrm{RH}$. Note that in both runs, only $\mathrm{T}$ and RH differ since total nitrate and ammonium input are the same.

CIMS inlet heating is similar for day $\left(\sim 50^{\circ} \mathrm{C}\right)$ and night $\left(\sim 60^{\circ} \mathrm{C}\right)$. Potential bias in the $\mathrm{HNO}_{3}$ or $\mathrm{HCl}$ then mainly depends on the mass loadings of $\mathrm{NO}_{3}{ }^{-}$or $\mathrm{Cl}^{-}$. Here we focus only on the possible bias due to overmeasurement of $\mathrm{HNO}_{3}$. ISORROPIA-II was run at ambient $\mathrm{RH}$ and T with a "corrected" $\mathrm{HNO}_{3}$ at three assumed lower levels of $\mathrm{HNO}_{3}$ to compensate for an assumed positive nitrate artifact of $10 \%, 20 \%, 30 \%$ (i.e., assuming 10, 20 or $30 \%$ of the nitrate measured by the AMS or PILS was evaporated in the CIMS inlet leading to an over-measurement of $\mathrm{HNO}_{3} .10 \%$ to $30 \%$ particle $\mathrm{NO}_{3}{ }^{-}$was subtracted from the measured CIMS $\mathrm{HNO}_{3}$ ). Only $\mathrm{HNO}_{3}$ is modified, all other inputs are kept the same. Results are shown in Fig. S8. Evaporation of $30 \%$ of the measured nitrate is expected to be an extreme upper limit. For instance, $66 \%$ of $\mathrm{PM}_{1}$ nitrate evaporated at a temperature of $75^{\circ} \mathrm{C}$ in a thermal denuder upstream of the AMS at the CalNex site, consistent with previous results at other urban sites in the LA area and elsewhere (Huffman et al., 2009). The residence time on the thermal denuder was $\sim 12 \mathrm{sec}$, while that of the CIMS inlet was $\sim 0.32 \mathrm{sec}$, so the extent of evaporation in the CIMS inlet assumed to be substantially lower than that in the thermal denuder. 

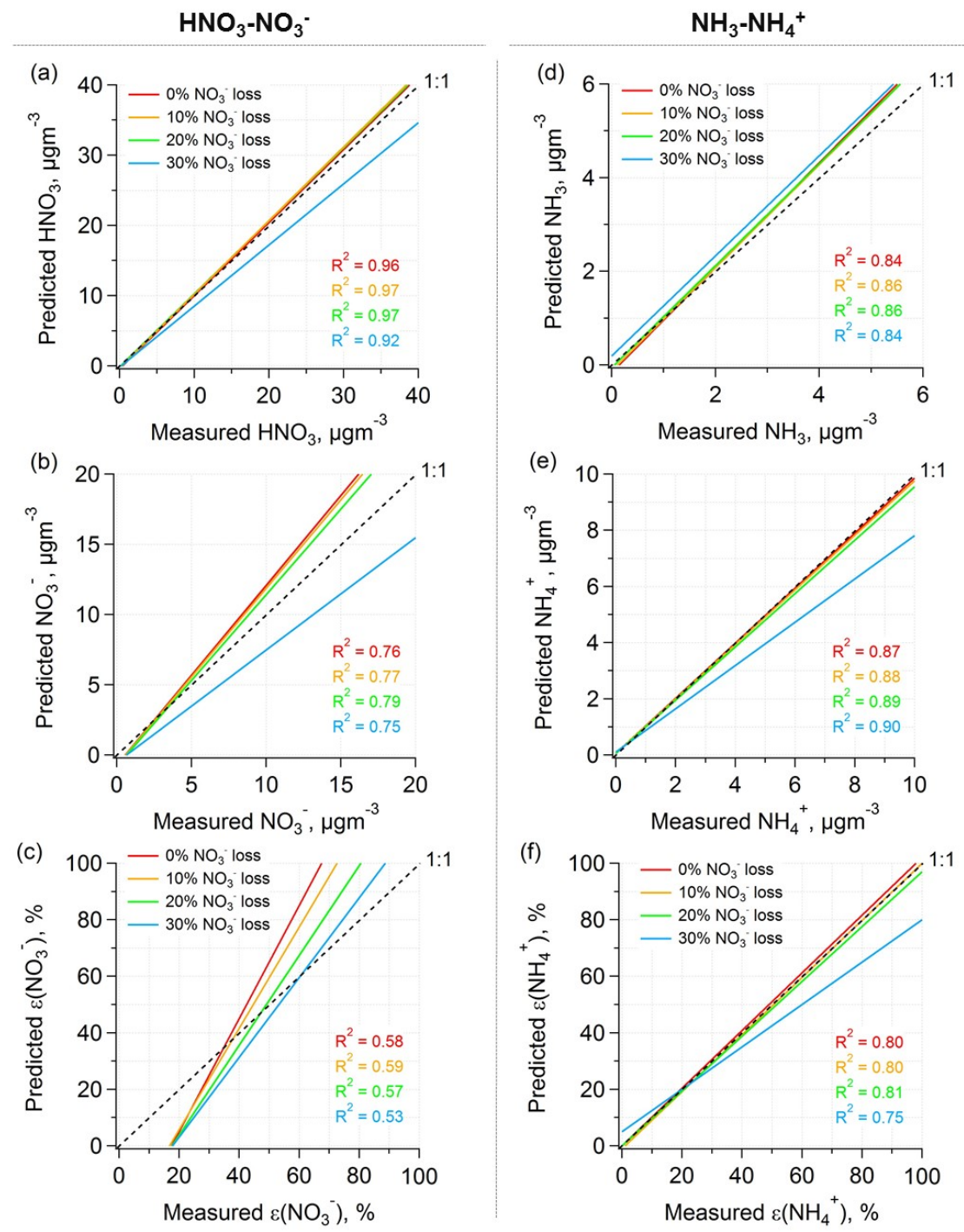

Fig. S8. Comparisons of predicted and measured $\mathrm{HNO}_{3}, \mathrm{NO}_{3}{ }^{-}$, and $\varepsilon\left(\mathrm{NO}_{3}{ }^{-}\right)(\mathrm{a}, \mathrm{b}, \mathrm{c})$ and $\mathrm{NH}_{3}, \mathrm{NH}_{4}{ }^{+}$, and $\varepsilon\left(\mathrm{NH}_{4}{ }^{+}\right)(\mathrm{d}, \mathrm{e}, \mathrm{f})$ for data from the complete CalNex study based on "corrected" $\mathrm{HNO}_{3}$ data due to assumed $\mathrm{PM}_{1}$ nitrate evaporation in the heated CIMS inlet. The other inputs are kept the same. Only the orthogonal regression fits are shown. " $0 \% \mathrm{NO}_{3}{ }^{-}$loss" condition is the same as Figure 2 in the main text. 
Fine particle $\mathrm{pH}$ and gas-particle phase partitioning of inorganics during the 2010 CalNex campaign

\section{References}

Alduchov, O. A., and Eskridge, R. E.: Improved magnus form approximation of saturation vapor pressure, J Appl Meteorol, 35, 601-609, doi: 10.1175/1520-0450(1996)035<0601:Imfaos >2.0.Co;2, 1996.

Carslaw, K. S., Clegg, S. L., and Brimblecombe, P.: A Thermodynamic Model of the System $\mathrm{HCl}^{-\mathrm{HNO}_{3}-}$ $\mathrm{H}_{2} \mathrm{SO}_{4}-\mathrm{H}_{2} \mathrm{O}$, Including Solubilities of $\mathrm{Hbr}$, from $<200$ to $328 \mathrm{~K}$, Journal of Physical Chemistry, 99, 11557-11574, doi: 10.1021/j100029a039, 1995.

Clegg, S. L., and Brimblecombe, P.: Equilibrium Partial Pressures and Mean Activity and Osmotic Coefficients of 0-100-Percent Nitric-Acid as a Function of Temperature, Journal of Physical Chemistry, 94, 5369-5380, doi: 10.1021/j100376a038, 1990.

Clegg, S. L., Brimblecombe, P., and Wexler, A. S.: Thermodynamic model of the system $\mathrm{H}^{+}-\mathrm{NH}_{4}{ }^{+}-\mathrm{SO}_{4}{ }^{2-}-$ $\mathrm{NO}_{3}{ }^{-}-\mathrm{H}_{2} \mathrm{O}$ at tropospheric temperatures, J Phys Chem A, 102, 2137-2154, doi: 10.1021/Jp973042r, 1998.

Fountoukis, C., and Nenes, A.: ISORROPIA II: a computationally efficient thermodynamic equilibrium model for $\mathrm{K}^{+}-\mathrm{Ca}^{2+}-\mathrm{Mg}^{2+}-\mathrm{NH}_{4}{ }^{+}-\mathrm{Na}^{+}-\mathrm{SO}_{4}{ }^{2-}-\mathrm{NO}_{3}{ }^{-}-\mathrm{Cl}^{-}-\mathrm{H}_{2} \mathrm{O}$ aerosols, Atmospheric Chemistry and Physics, 7, 4639-4659, doi: 10.5194/acp-7-4639-2007, 2007.

Guo, H., Sullivan, A. P., Campuzano-Jost, P., Schroder, J. C., Lopez-Hilfiker, F. D., Dibb, J. E., Jimenez, J. L., Thornton, J. A., Brown, S. S., Nenes, A., and Weber, R. J.: Fine particle pH and the partitioning of nitric acid during winter in the northeastern United States, Journal of Geophysical Research: Atmospheres, 121, 10,355-310,376, doi: 10.1002/2016jd025311, 2016.

Hayes, P. L., Ortega, A. M., Cubison, M. J., Froyd, K. D., Zhao, Y., Cliff, S. S., Hu, W. W., Toohey, D. W., Flynn, J. H., Lefer, B. L., Grossberg, N., Alvarez, S., Rappenglück, B., Taylor, J. W., Allan, J. D., Holloway, J. S., Gilman, J. B., Kuster, W. C., de Gouw, J. A., Massoli, P., Zhang, X., Liu, J., Weber, R. J., Corrigan, A. L., Russell, L. M., Isaacman, G., Worton, D. R., Kreisberg, N. M., Goldstein, A. H., Thalman, R., Waxman, E. M., Volkamer, R., Lin, Y. H., Surratt, J. D., Kleindienst, T. E., Offenberg, J. H., Dusanter, S., Griffith, S., Stevens, P. S., Brioude, J., Angevine, W. M., and Jimenez, J. L.: Organic aerosol composition and sources in Pasadena, California, during the 2010 CalNex campaign, Journal of Geophysical Research: Atmospheres, 118, 9233-9257, doi: 10.1002/jgrd.50530, 2013.

Huffman, J. A., Docherty, K. S., Aiken, A. C., Cubison, M. J., Ulbrich, I. M., DeCarlo, P. F., Sueper, D., Jayne, J. T., Worsnop, D. R., Ziemann, P. J., and Jimenez, J. L.: Chemically-resolved aerosol volatility measurements from two megacity field studies, Atmospheric Chemistry and Physics, 9, 7161-7182, doi: 10.5194/acp-9-7161-2009, 2009. 